\title{
A new Late Triassic dipteridacean fern from the Paso Flores Formation, Neuquén Basin, Argentina
}

Silvia Cristina Gnaedinger and Ana María Zavattieri

Acta Palaeontologica Polonica 66 (4), 2021: 885-900 doi:https://doi.org/10.4202/app.00864.2020

Sterile and fertile fronds of dipteridacean ferns from the Paso Flores Formation (late Norian-Rhaetian) at Cañadón de Pancho area, south of the Neuquén Province, Patagonia (Neuquén Basin), Argentina, are described. The Paso Flores Formation specimens comprise an interesting mixture of features showing a unique combination that does not fit in the diagnosis of any of the known fossil genera of Dipteridaceae. Characters such as the number and shape of primary segments in each rachial arm, the coalescence of the primary segments at the base of the frond, the distribution of sori and the number of sporangia per sori allow to differentiate the Paso Flores Formation specimens from the other genera of the family. The new genus and species, Patagoniapteris artabeae is proposed. The specimens share some frond morphological features with the fossil genera Clathropteris, Digitopteris, Thaumatopteris, Sewardalea and with some species of the Dictyophyllum, as well as the characteristic of the sori with the living species Dipteris lobbiana. The Paso Flores Formation environments developed on the western margin of Gondwana under seasonal temperate-warm and humid to sub-humid climates with a marine influence from the west. The Cañadón de Pancho assemblages are late Norian-Rhaetian in age, being the youngest fossil flora recorded from Argentinian Triassic basins to date.

Key words: Gleicheniales, Dipteridaceae, Norian, Rhaetian, Paso Flores Formation, Neuquén Basin, Patagonia, Gondwana.

Silvia Cristina Gnaedinger [scgnaed@hotmail.com], Área de Paleontología, Centro de Ecología Aplicada del Litoral, Consejo Nacional de Investigaciones Científicas y Técnicas (CECOAL-CCT CONICET Nordeste, UNNE), Facultad de Ciencias Exactas y Naturales y Agrimensura, Universidad Nacional del Nordeste (FaCENA-UNNE). Casilla de Correo 291, 3400 Corrientes, Argentina. Ana María Zavattieri [amz@mendoza-conicet.gob.ar], Departamento de Paleontología, Instituto Argentino de Nivología, Glaciología y Ciencias Ambientales (IANIGLA-CONICET), Av. Adrián Ruiz Leal s/n, Parque General San Martín, M5002IRA, Mendoza, Argentina. 
This is an open-access article distributed under the terms of the Creative Commons

Attribution License (for details please see creativecommons.org), which permits unrestricted use, distribution, and reproduction in any medium, provided the original author and source are credited.

Farf Full text $(3,219.1 \mathrm{kB})$ 